\title{
Socio-environmental conflicts and the struggle for the Southeaster territory of Pará
}

\author{
María de los Ángeles Guevara \\ Edma Silva Moreira
}

I Phd. Philosophical Sciencies. Guest professor of Programa de Pós Graduação em Desenvolvimento e Extensão da Universidad Federal de Lavras, Minas Gerais - Brasil.

${ }^{\text {II }}$ Phd. Social Sciencies. Professor in: Universidade Federal do Sul e Sudeste do Pará (Unifesspa), Marabá, Pará - Brasil.

\begin{abstract}
In the Eastern Amazonia, socio-environmental conflicts are increasing as their wealth is valued by transnational capital, the basis for the re-concentration of land according to global interests. The objective is to reflect on socio-territorial dynamics that involve socio-environmental conflicts and struggles by a multiplicity of social actors. The methodology followed comprises direct observations of the context of study, interviewing and the reading as well as interpreting the sources. The results show that land and territory are the basis on which other conflicts are built and branched, all of which can be branded as socioenvironmental. The resistance to the processes of de-territorializing resignify the role of social actors in the struggle for the territory.
\end{abstract}

Keywords: Eastern Amazonia; Socio-environmental Conflicts; Power; Social Struggles.

São Paulo. Vol. 23, 2020

Original Article

DOI: http://dx.doi.org/10.1590/1809-4422asoc20180252r1vu2020L6AO 


\section{Introduction}

Socio-environmental conflicts, inherent to the global expansion of capitalism, are frequent in places rich in resources with devastating impact on the local biodiversity as a whole. Thus, causing forceful displacements, destroying resources and ways of living, contaminating sources of drinking water and breathing air, all of them processes which are not performed without resistance.

Merchandizing nature, which increased during the 90`s, responds to Miningenergetic demands of transnational capital, named by lo Harvey (2004) as "accumulation of dispossessions". In this process Latin America ratifies its position as exporter of raw material and thus privileges in the region are granted to the transnational capital above the rights communities have on their territories.

"Mining boom", water and other resources demand is the signature of the economic practices of a model that wants growth in exchange for lives, a model defined as Neo-extractive (GUDYNAS, 2009). A model that breaks identities, ways of being and doing, weakens the rights, dismantles the social networking, de-territorializes, changes the landscape and causes tense relationships with nature.

Eastern Amazonia ${ }^{1}$ gathers both one of the largest amounts of socio-environmental conflicts as well as of struggles for territorial defense resistance in Brazil. The Pastoral Commission for Land (CPT by its Spanish acronym) identified that $57 \%$ of the conflicts in the countryside and 79\% of the murders in all Brazil during 2016, were concentrated in this territory (CPT, 2017, p. 107-109). In 2018, only Pará registered 62, 239 conflicts (CPT, 2019 p. 65-66), proving that conflicts increase in the same proportion that natural resources are valued by the transnational capitals. Then a territory such Southeastern Pará becomes strategic to global geopolitics, a melting pot for re-concentrating the land for the purpose of global interests. These processes operate in the shadow of power, which examples may always be found in the testimonies of the social actors, thus unveiling their questionings about democracy in a context curtailing their rights to the territories.

Socio-environmental conflicts are being understood as those generated by megamining, conflicts for land, for drinking water, for forest resources, all involving resistance from the social actors against the processes destroying their territories and their way of living; they incorporate their perceptions, senses and values about development and their relationships with nature. Due to their impact on social metabolism as well as for their significance for historically marginalized groups, we are also including the conflicts for land among this group.

The methodology ${ }^{2}$ used in this study valued the direct contact with the daily activities which allowed observing in the context. Unstructured interviewing ${ }^{3}$ was the main tool to recover testimonies about the socio-environmental conflicts, allowing the construction of knowledge which emerges from in situ time sharing and watching thus

1 - Eastern Amazonia includes the states of Pará, Amapá, Tocantis and part of the state of Maranhão.

2 - The work field was performed in 2016 and the first semester of 2017 with still another two entries on 2018. During this time the authors accompanied meetings, gatherings, public hearings and other occurrences relevant for the investigation. 3 - We keep privacy for some of the identities of the personal opinions quoted in the article. 
valuing experiences. We also added analyzing and interpreting texts.

The epistemic perspective is supported by contributions from the Critical Political Ecology, to dive into the complexity of the socioenvironmental conflicts from Southeastern Pará ${ }^{4}$, in the way the different struggles for territory and defending nature, are articulated. In this same way the characterization made by Eduardo Gudynas (2009) about "the predator extractive model" or Maristella Svampa (2008) about "the consensus of commodities" allow to match the conflicts with the way social actors question development and build their environmental rationalities. In the case of Brazil, the studies and compilations made by Acselrad $(2004,2014)$ are also valuable.

Feminism from the South allowed to value knowledge anchored in women`s experiences, as well as to build contextualized knowledge, thus making it possible to democratize epistemic subjects. It is also valuable to promote reading reality through the keys provided by Critical Ecofeminism from the Third World. This decodes the logic of historical domination from patriarchy which allowed to keep and justify domination over nature and women.

Thus, the goal is to reflect on the dynamics that involve socio-environmental conflicts and highlight the voices of resistance. We start with a reflection from the conceptual tools of Critical Political Ecology and Ecofeminism, then we continue with an analysis of the territory as a field of socio-environmental conflict, later we analyze the developing program the government proposes and its environmental impacts. In the end, conflicts generated by "the development" proposal made by the Vale S.A. transnational are debated about and the struggle of the social actors, among them of the Babaçu Coconut ${ }^{5}$ Women Breakers which allowed to argue why these situations are also a feminist problem. Finally, conclusions are provided.

\section{Socio-environmental conflicts viewed from the keys of Political Ecology and Ecofeminism.}

Socio-environmental conflicts are related to rationalities and logical thinking about the territory and its resources, as well as to speeches about "development", democracy and to the values we give to nature, always contextualized by power relationships. As many studies show, in Latin America conflicts are related to mega-mining and to the expansion of the agricultural commodities, etc., which generate, as in the case of Southeastern Pará, the dispossession of the land and of the territory:

$[\ldots]$ by means of extractivist schemes the production of the most persistent of all forms of social inequalities, that is ecologic or socio environmental inequality, occurs: the fact that specific societies or groups usufruct and consume increasing portions of ecosystemic

\footnotetext{
4- Southeastern Pará is formed by 14 municipalities. It covers approximatelly $54,469 \mathrm{~km} 2$, with a population of over 617 thousand inhabitants in 2015 (IBGE, 2015)

5 - Removing the thick ledger from the fruit has traditionally been made by women, thus they are known as "Babaçu coconut breakers". They use the whole palm tree, and for many municipalities this is the main source of income for rural families.
} 
resources and services at the expense of displacement and/or degradation of the living conditions of other human beings (MACHADO ARAOZ, 2015, p. 13).

Critical Political Ecology provides an interdisciplinary perspective as well as enough empirical support to analyze the colonization processes of nature. Martìnez Alier (2004), defines the environmental conflicts as ecological-distributive conflicts, which refers to the inequalities in the use and distribution of resources. Political Ecology for this author also defines a wide social and political movement for Environmental Justice. These movements are known as "the ecology of the poor" (MARTINEZ ALIER, 1998), for example the movements present in the context of the study, such as "The affected by the dams", the "Movement against Mining" or the Interstate Movement of the Babaçu Coconut Women Breakers".

According to Martìnez Alier (2004), environmental conflicts are expressed through different languages for assessment: ecological, cultural, language of subsistence and through economic values contained in speeches, as an expression and feelings for the losses suffered. For example, when we hear the complaints of the population displaced by Tucurui dam "we lost the place, the land, the water, our fish" (FEMALE LEADER OF GAVIOES ABORIGINALS, 2016) or when a female farmer says that the Vale S.A. Enterprise "only leaves behind hurricanes and sick bodies" (FEMALE INHABITANT OF ONE OF THE VILLAGES, 2016). Thus showing how the environment is incorporated into the conflict.

In Political Ecology the use of concepts, for example environmental and socioenvironmental conflicts, meets diverse criteria of classification ${ }^{6}$. We use socio-environmental conflicts to emphasize on the power relationships the processes of appropriation of territory go through, to emphasize on the values, cosmogony and confronted interests expressing opposite ontologies. We understand, following Fontaine (2004), that there is no "environmental conflict" without a social dimension as the denial of communities and social groups 'rights are always present. According to Leff (2004), ecology degradation is the mark of the civilizing crisis with its economic rationality denying nature; thus analizing social conflict as if "emerging from the dominant ways of appropriation of nature and from the environmental contamination" (LEFF, 2006, p. 23).

In Latin America most authors relate the increase of socio-environmental conflicts with the expansion of the extractive ${ }^{7}$ model in the area, defined by Svampa (2008) since the end of the 20th century, as conflicts due to the access and control of the natural resources and of the territories, which implies having divergent values and interests on the part of actors in a greatly asymmetrical power context. In this sense, “...environmental conflicts present in the territories mentioned are an expression of emerging critiques to

\footnotetext{
6 - The detailed analyses made by Eduardo Gudynas (2014) in "Conflicts and extractivisms: concepts, contents and dynamics", where he defines extractivism as a particular case of great scale extraction of natural resources mainly for exporting them.

7 - Information about conflicts might be received through the Observatory of conflicts for natural resources (OCRN) (By its Spanish acronym) http://www.avina.net/esp/10427/incontext-32/\#sthash.rQiTIOfa. dpufhttp://ocrn.info/
} 
the "development" projects sustained by collective subjects whose land which are already threatened by expropriation or in the process of being expropriated." (ACSELRAD, 2014, p. 89).

In order to overcome conceptual limitations, Eduardo Gudynas defines these conflicts as

dynamic of oppositions, resulting from different assessments, perceptions or meanings about actions or circumstances linked to society or to the environment, running as a process being expressed in collective actions, where opposite actors interact publicly among themselves (GUDYNAS, 2014, p. 87).

No matter conflicts being defined as environmental, social, economic, and territorial, among other types, as emphasized by this author, "the common distinction between "social and socio-environmental" conflicts is uncertain, because strictu sensu all conflicts are always social, as it is a dynamic of opposite social actors" (GUDYNAS, 2014, p. 87).

Considering the dynamics involving the conflicts in the Southeastern Parà, we may classify them as "high intensity conflicts" taking into account the violence of the dispossession, the police actions accompanying the enterprises` decisions, killings and deaths, criminalization of the resistance, etc. In this same way they are diverse regarding their content, for example some emphasize more on the struggle for land and territory, such as the cases of the aboriginal villages or dispossessed or displaced populations; others face wood dealers through women and environmentalist leaders; while others are focused on the contamination, diseases and deaths caused by open air mining and mineral transportation; still some others face contamination of the water supplies due to construction of hydro ways or displacements; yet some others fight for symbolic territories such as the Babaçu Coconut Women Breakers. It is very hard to group them due to their complexity and the diversity of their struggle of resistance, thus we use the term socio-environmental conflicts.

It becomes difficult from the Political Ecology perspective answering to questions such as: how is the new extractive model related to the life of women? Or how conflicts and violence materialize in their bodies? Dialogues between this field of knowledge and Ecofeminism are not enough yet and it is not the subject of this article. That is why it is necessary to appeal to Ecofeminism.

A reality that interrelates several ways of domination, that generates specific experiences in women, enforced by other ways of domination such as class, gender, ethnic, color of the skin, age domination, etc., and the global patriarchal violence in the territories where mining expansion supplanted traditional economic activities, displacing women from those income generating spaces, such as the extractive activity of herbal medicine, of Babaçu coconut, fruits or food production, over dimensioning their place in the reproduction of life.

The anthropocentric profile of the development model is not only aimed at controlling nature but at colonizing bodies as well. This issue is vastly and critically analyzed 
from Ecofeminism, emphasizing that marginalization of women and the destruction of the biodiversity originate on the patriarchal model (MIES; SHIVA, 1998). Vandana Shiva considers that:

the main threat for nature and people comes from the centralization and monopolization of power and control, which impulse generates one-dimensional structures $[\ldots]$. Such cultures menace diversity as a disease and create coercive structures to biologically and culturally model this diverse world of ours on the privileged categories and the concepts class, race and gender of only one specie (SHIVA, 2007, p. 53).

Emphasis is made on the need to look at the environmental aspects always from the power relationships that the gender goes through to account for the framework of conflicts and deconstruct dual hierarchies that modernity has placed on women and nature as another dominated and even merchandized being. Maybe this philosophy justifies the high index of sexual violence, prostitution and the appearance of the so called "sons of mining", who accompany the biggest S11D mining project started by the Vale S.A. Enterprise in Southeastern Parà. Studies made by the Brazilian institute of Social and Economic Analysis show their impact; among them an overdue growth of the floating population, mainly of men for the first stages of the project (IBASE, 2018).

Looking at the conceptual tools from Ecofeminism is what Alicia Puleo has termed as "own keys of Ecofeminism to reflect about the environmental issue from patriarchal, androcentric, care and sexist and gender categories" (PULEO, 2011/2012, p. 57). To appeal to a dialogue between ecology and feminism allows for connecting the impacts of mining expansion with nature deterioration and the means of earning their lives for these women, in the same way they become protagonists of their re-existence.

Beyond Critical Political contributions, it is necessary, following (WARREN, 2003) to dismantle the comprehension generated by the logic of domination which has historically operated from patriarchy to keep and justify the twin domination of women and nature.

\section{The territory as a field of socio-environmental conflicts}

The territory is a field of social conflicts for power expressed as in the case of study, in continuous processes of struggle for the access, appropriation, dis-appropriation, reappropriation of the space as,

Nowadays we are witnessing the implementation of the "reorganizing spaces and territories" policies which are not the direct product of the gradual expansion of the exchanges but the effect of the state's deliberate protectionist action, aimed to restructuring markets, disciplining the comercialization of land, forest and subsoil resources 
(ALMEIDA, 2010, p. 63).

This political and economic action of domination does not encourage dialogue between the actors in the territory, while it disciplines and controls it lucratively, not considering its productive practices, as a farmer from an area affected by mining has said "when people started planting some beans and manioc, the federal order came to throw them out" (PEASANT INTERVIEWED, 2016). In that sense, the political action of the State promotes de-territorializing and keeps distant from the construction of democratic occupational practices of space, and from acknowledging its rights.

For Fernandes (2005), "the territory is the adequate space for a specific social relation which keeps and produces it according to a form of power". The territory is, in this way, a social construction, where the interests and forces of economic and political agents generate the web of relations in the political, productive, administrative, ecological, cultural and commercial fields.

Due to the multidimensional character of the concept of territory, our reflection considers its economic dimension to be relevant, as it allows to analyze the interests at play and their symbolic dimension, that refers to the re-appropriation process from social inclusion, values and knowledge, historically accumulated in the collective memory that is, as a dialectical process. It is updated in the own dynamics of daily activities: fishing, planting, collecting, and performing their pedagogical and religious practices.

It is valid to highlight that the symbolic dimension comes from incorporating the representations of the social actors above their spaces, habits, values and way of living which depend on the objectively available resources and their competence to use them. (BOURDIEU, 1989). These representations operate in the territory in the same way the actors involved refer to not merely physical spaces, for example the immemorial space of the aboriginals, the mythical and sacred spaces in the forests, rivers and in the land protected by the farmers, as they have practical senses for the collective life, either for obtaining a prosperous harvest or for obtaining products for their healing and protection rituals.

The value granted to nature differentiates from the economic rationality aimed for lucrative results. Its significance lies on the indissoluble relationship between human beings and nature which involves needs and care, since it cradles the goods necessary for life, thus in need to be preserved.

This perspective mobilizes us to the use of environmental dimension, meanwhile social actors such as women fight and resist the hegemony of the forests ' predator model, the interests of the wood dealers. And this takes place at a local and family scale of the environmental handling of spaces from which their survival depends, without neglecting the political dimension inherent to the social network. These dimensions were analyzed by Haesbaert (1997).

On the appropriated space, power relations are articulated and its respective resistances act as micro powers. In this sense we use the concept of territory provided by Raffestin (1993), Haesbaert (1997), Saquet (2003). Main currents about the conceptu- 
alization of territory are valued by Freitas (2008). These authors'perspective is valid to understand the processes of de-territorializing and re-territorializing, the interaction of social and economic agents that resist and modify the structures of power at the micro level, thus re-territorializing the space.

Hence, we consider that the space provides significant changes operated by historically-excluded-from- "development" actors, whose social movements cause friction on social structures, exposing the ways of domination of the hegemonic forces, capitalist enterprices, local elites and the State (WANDERLEY, 2011). They place on relief the different territories on dispute, proving that socio environmental conflicts wrap the complexity of life in society, in which not all actors have the same access or equally share the same resources, as this depends on their positions or dispositions in that territory, resulting from the amount of capital they have mobilized (BOURDIEU, 1989).

One of the capitals mobilized by the studied actors is the cultural-symbolic one, which is strongly present in their daily practices, sustaining their permanent struggle for the land, the forests, the water supplies and their territory, and becoming their way to show their autonomy and emancipation as collective subjects whose diverse identities materialize in their movements of struggle against the hegemonic domination of the culture of exploiting nature with lucrative objectives; that is, with an utilitarian purpose (THOMAS, 2010; LEFF, 1995).

They are the social movements in defense of their territories, where their culture is legitimately expressed, allowing them a social cohesion in constant transformation regarding their life experiences. With these regards a rural worker from Serra Dourada Planalto Camp, an area in dispute with the Vale S.A mining company, states that what joins them in the camp is the struggle for the land, as "we only want to plant, to cultivate our food [...], work the land" (INHABITANT OF ONE OF THE VILLAGES, 2016).

Socio-environmental conflicts are processed from the struggles for access to the resources that guarantee the life of the people from the forests, from the waters, from the country side. Their different logics about these resources and the affirmation of a culture which perceives, feels and assumes nature as an extension of its own life; are thus processed by evoking the need to care for nature with justifying and symbolic practices opposed to those utilitarian ones for which the problem of the destruction of nature is even considered universal.

An aboriginal leader has referred to that utilitarian and destructive character as it follows:

[...] Besides, Vale is at risk, I was told that, because (pause) Vale has the tendency just to destroy, to destroy and it does not matter who is going to buy, so it continues taking the minerals out of the country, where will the aboriginals go?, where are they going to live?, how and out of what is the aboriginal going to live? And white men with no living conditions where are they going to live? $[\ldots]$ then, there is a serious risk that Vale one day will be suspended and the people will understand what they have been causing and no one will buy more 
iron or gold, then it will stop. Where will they take the minerals for selling then? (PAIARÉ, 2013, apud RIBEIRO Jr., 2014, p. 64).

Bourdieu's reflection (1989) that conflicts are the extension of social practices from social agents and that existing disputes are related to their positions and dispositions in social space as they depend on mobilized capital. They allow us to visualize that in the field of struggles for territory and for natural resources there are differentiated cultural, political and environmental logics through which we visualize the place of the Amazonian population in their struggle for their territory. Socio-environmental conflicts evoke the right to life, the deepest aspect of the meaning of mankind. The objective and symbolic struggle for territory carries itself that meaning, which is also its sense about the world.

The analytical treatment about social struggles in the Amazonian area from the 90`s reports the struggle for the land as a right against the governmental 'forms of violence, as well as against capitalism model, implemented in the Amazonian area thus tearing it of socio-environmental life (HÉBETTE, 2004; MARTINS, 1993, 2016). Therefore, conflicts for land and territory are also an expression of resistance against the advance of a cultural model which permanently tries to separate men and women from their environment. Struggles of resistance are opposed to that process because they refuse to be submitted to this kind of domination.

In this sense we come to review Foucault (2001), to understand that power and resistance are mutually implicated. They involve relationships among subjects which constitute, in a despair and heterogeneous way, a kind of microphysics, of micro powers, assisting individuals in the concretion of their bodies and penetrate in the daily objectivity and subjectivity of the production and reproduction of their actions, and disseminate throughout all their social structure.

By following this author, we may understand that every power relationship always necessarily generates possibilities of resistance, as practices fragmenting power and introducing alternative ways of existing. These possibilities are not for granted but they are always in the field of struggles against the submission of subjectivity (FOUCAULT, 197?). The resistances are not external but built-in within their own web of relationships, everywhere power traverses the individuals:

power needs to be analyzed as a circulating entity, or better, as something that only works in a chain. It can never be placed either here or there, it is never in anyone's hands, it is never adequate either as wealth or as a resource. Power works as a web. In its framework individuals are in a position to circulate but also to exercise and to suffer from power. Individuals are never inert targets or spoiled by power, they are always transmision centers. [...] Individuals are effects of power, its transmission center. Power travels through the individual ot has constituted (FOUCAULT, 2004, p. 183-184).

Within Foucault`s perspective power relationships always necessarily generate possibilities of resistance, of strategies, of escapes that invert the situation of the individual. 
For example, the experience lived by women in their daily life, the purposeful strategies they design, in the appropriation and use of the territories, create new relationships that re-signify socio-productive practices supported by principles of solidarity as an emancipatory positioning facing the "attachment" to the dominant model. While resisting, new subjectivities, new ways to exist as collective subjects are built among those who fight for the recognition of their identities and rights.

\section{Relationship between developmentalism and socio-environmental conflicts}

An analysis of what is recently happening in Southeastern Pará takes us to a recent past with the incorporation of the Eastern Amazonia to the megaprojects for capitalist modernization of Brazil with the implementation of the Gran Carajás Program (PGC by its Spanish acronym) in $1980^{\circ}$. As well as other projects related to the creation of needed infrastructures for the expansion of capita, such as roads construction, railway tracks, bridges, hydroelectrics, electricity lines ans other infrastructures of all kinds. However as shown by Pereira (2013) conflicts at Pará go way back to the beginnings of the 20th century with the sales of thousands of hectares of land by the government of the state and the issuing of titles of land favoring the local elites, and economic groups, among them those that were already exploiting the "Brazilizn nut".

The actions related to a developing policy towards the Amazonian area increased displacements, disputes for land, as well as environmental impacts. A description of the impacts of developing politics for the Amazonia, may be found in (HÉBETTE, 2004), who notes that the opening of important ways such as Transamazonic and others such as PA-070 and PA-150, the construction of Tucurui Hidroelectric, PGC the colonization politics and the stimuli to the entrance of the great capital were the center of the politics that would have irreparable damages in the Amazonian ecosystems with a total modification of the landscape. Hébette emphasizes:

[...] Great state and private capital...have remodeled the space, opening from south to north, from west to east, mines, dams, artificial lakes, high tension lines, rail way tracks, mineral waste tanks, all of these without considering both local and recently immigrated traditional populations. Great fishing and wood modernly equipped companies, looking for immediate lucrative results, have completed the social and environmental disaster [...]. With the consent of the state, the great capital has deepened the wound already opened in the Amazonian area [...], its impact has aggravated not only the environmental impact but also the social one (HÉBETTE, 2004, preface).

All of the above have generated demographic changes, some within the planned logics of capital, attracted by the slogan "men with no land for lands with no men" and others 
espontainously, such as mining in Sierra Pelada9. Buit all left their ecological print in the cpontinuing devastation of the Amazonian forest, as well as in the contamination of the hydric resources, of the land and the air.

Within this context the founding structure keeps showing high levels of concentration of the land, mostly related to extensive live stock farms, agrobusiness, linking the region to meat and grains exporting chains to the globalized transnational market. The advance of the agricultural border may be compared to what Marx called the Originated Acummulation of Capital (MARX, 1975) divided into categories dispossession, disassociation between the producer and the land as main mean of production.

Southeastern Pará is not an isolated case, it is just another one within global strategy of trans-nationalized capital, a second generation of reforms after "Washington Consensus", aimed at the re-prevailing of the economy. This is a process full of legal mechanisms to concretize the dispossession ${ }^{10}$. These practices are also resulting from the alliances between the transnational enterprices and the state; such as, for example what happens in the Mosaic of the "Conservation Unit of Carajás" where Vale S.A. actions. A female leader member of the movement of rural workers reveals this situation "an area with 250 families and a judge of recovery (for the farmers). What (is) more important? Families starving to death or a preserved forest?" (FEMALE LEADER, 2016). Undeniable examples of processes operated in the shadow of power are always present in the narrations of affected social actors.

This indicates that the territory is in the center of a conflict marked by an unequal access to the resources. The agricultural policy followed favored the concentratiom of power from the greeat latifundia and from Vale S.A. enterprice. It offered limited possibilities to social reproduction of agricultural farming, neglecting the historical presence of the aboriginal groups.

Pillage (grilhagem ${ }^{11}$ ) and consequently gunning (pistolagem ${ }^{12}$ ) are part of the process of dispossession and appropriation under the shadow of power. Thus, struggles for land and resistance are becoming an expression of the agrarian reform from inside, made under the pressure of the organized social movements which are common in the area since the 90 's, because the existing legal devices do not make themselves things happen.

Southeastern Pará is one of the territories with the best examples, due to the number of settlements acquired during the struggle for land ${ }^{13}$. It is considered a territory of appropriation and construction, defined by Fernandes (1999) as "territorialization of the struggle for land"; thus originating not a few socioenvironmental conflicts which may

\footnotetext{
9 - It started at the end of the 70's and it gathered over 50.000 "garimpeiros". After 1986 a community marked by poverty and marginality was originated there, where around 6.000 families live.

10 - Such as the creation of environmental reserve areas, concessions to transnational enterprises, approval of support legal instruments, paralyzation of the Agrarian Reform, the use of government violence, criminalization of social movements in resistance, etc.

11 - Grillhagem is the term used to identify the appropriation of land through violence and illegality.

12 - Name given to those employed by the persons in power, who become hired murderers, thus killing male and female rural workers.

13 - Between 1987-1996 the number of villages was 86 and 10 years later in 2006, they have reached the number of 473 , with a disappropriated area of 4, 395, 555, 9805 hectareas. According to the information provided by INCRA (03.04.07) and organized by Pereira (2013, p. 217).
} 
get to the murder of those defending the forests ${ }^{14}$ :

Pressure from farmers is part of the daily life. It is anguishing to remain in silence, it is better to continue. The farmer who ordered the murder bought three plots at the settlement $[\ldots]$ we are under the farmers' pressure all the time and plots are bought all the time. [...] (INHABITANT A FROM ONE OF THE SETTLEMENTS, 2015).

Women organized in productiuve groups depending on the Amazonian forests are in conflict with the patriarchal power that culture imposes:

the same owners are cutting down the trees. The gravest ones are the charcoal producers $[\ldots .$.$] . The forest is diminishing, it's being$ substituted by pastureland, we do not accept this [...], but the credit stimulates cattle raising $[\ldots]$ culture has changed, there are persons with different traditions, rach life is a story, a lot of people suffer [...] as a teacher I encouraged the students to diagnose the family plot, even the quality of water [...] I explained to them that of we deforest the area, we will not only end the forest butu also the water supplies [...] (INHABITANT B OF ONE OF THE VILLAGES, 2015).

\section{Mining: the "developing" fallacy and socio-environmental conflicts}

Eastern Amazonian has the biggest iron mineral reserve in the world as well as some other minerals which extraction and transformation is made through the Vale S.A. Enterprise. This one has started to operate in the Carajás Complex since 1985, demanding infrastructures such as Tucurui hydroelectric, steel industry and an $892 \mathrm{~km}$ long railway track reaching Puerto Maderas in San Luis, Maranhão, as a proof of the "spill effect" of mining (GUDYNAS, 2016).

The wealth exiting the country contrasts with the poverty remaining, considering the over 1, 5 million persons at the state of Pará who live in pauperism $(18,9 \%$ of the population, on top of about 1, 7 million in the same conditions in the state of Maranhão (PINASSI; CRUZ NETO, 2015, p. 86). The prospectives up to the year 2030, estimates an income of 90, 3 billions of dollars with the project S11D (COELHO, 2015, p. 64), thus turning the Vale S.A. Enterprise into the biggest mining company in the world as well as the biggest landowner of the state of Pará. These parameters also place this company in those same rankings due to the socio-environmental conflicts it generates.

The fallacy that makes believe that mining boosts development needs to be dismounted. Gran Carajás project increases de-territorializing as a predator act going through bodies and subjectivities. It twists identities, destroys ways and means of living, while imposing an ontology that breaks historic ways to relate with nature. Proofs have been found that the railway track through all its way affects over a million persons in 26

14 - In 2013 the environmental leaders María do Spíritu Santo Silva and her husband were murdered at the agroextractivist village Praia alta de Piranheira, located in the municipality of Nova Ipixuna. 
municipalities (COELHO, 2015, p. 50), same way as mining pollutes the air, sources of drinking water and consumes lives.

The narrative of one of the subjects in the camps reveals the extent of the destruction, constantly masked in the Environmental Impact Reports subsiding the licensing, when he said: "the impact at some water streams, I saw there several dead fish. I searched what had happened and I realized you needed to have an enterprise environmental license to do that" (INHABITANT OF ONE OF THE VILLAGES, 2016).

The predator logic of territorializing capital, ignites variables of an ontology where the human and non-human sides are considered objects of domination, thus sacrificing worlds of social and natural lives. It should be enough to quote:

after four decades of exploring the Carajàs region, the results of the "advances" made could not have been worse: over a million hectares of chest nut tree plantations destroyed, all the wood with commercial interest was removed from the area, forest has been burned down to make pasturelands, rivers and streams of water have been contaminated. Hundreds of rural producers, aboriginals, representatives of movements of struggle and of the church have been threatened and murdered [...] (PINASSI; CRUZ NETO, 2015, p. 93).

Only in 2016, the S11D project was responsible for conflicts that affected 484 families in Southeastern Parà;, Carajàs Railroad affected the aboriginal territory of Mae Maria, home of the Gavioes aboriginals in Bom moreover Jesus municipality, causing the resistance of 300 aboriginal families. Conflicts for drinking water sources and territory are known between the Vale S.A. Enterprise and the Xikrin aboriginals from Catetè and Djudjè-ko villages in Paraupebas municipality (CPT, 2017).

Who is benefited by the kind of "development" promoted by the megaprojects?, what kind of a development is that one which de-territorializes, dispossesses, re-colonializes the bodies of men and women, depriving them from their means of living and from life itself?. What kind of a development is that one that destabilizes natural cycles? In that sense, a female leader, with her territory flooded by the Tucurui dam, questions the development promoted by the megaprojects:

I do not even know if it existed [...]. It is so difficult for us to imagine that this is development. We see so much suffering, even with the development they have, a lot of people suffering, lots of difficulties, people struggling for life. What I know is that our life has been very painful with all these changes moving from one place to another (FEMALE LEADER, an inhabitant of one of the expropriated territories, 2018).

She recognizes that the promoted development caused the loss of her place and her way of living, both these issues arising profound sensitivity and feelings. Perhaps, the best concept qualifying that phenomenon is the notion of "mal-development" reviewed by Maristella Svampa and Enrique Viales (2014), to explain the anomalies of "Development" 
as a failure of the developmentalist programs. In the meantime, these proposals widen the gaps of social and gender inequalities; they sharpen conflicts for land, for territory and they also cause tension above nature.

Some decolonizing epistemologies question the modern myth about development. Authors such as Esteva (2009), Escobar (2010), Gudynas (2009), show a Latin-American way of thinking, emerging from what has been called "post-development". This notion emerged within the field of studies about development which deconstructs the speech and visualizes other practices of knowing and doing, other knowledge production agents which "have elaborated what could be known as an alternative political ecology based on notions of sustainability, autonomy, diversity and alternative economies that do not conform to the dominant speech of development" (ESCOBAR, 2005, p. 22).

Among its followers, there are commonalities in their economic and cultural analyses; in the respect for what is local as a space of alternative strategies, as well as in the contributions of the social agents to their struggles and daily practices and to the construction of other ontologies and visions of development. Escobar (2005) analyses that combining post-development elements, the postcolonial theory, political economy and feminism has been important to achieve a new understanding of development. Nonetheless, knowledge produced by the social movements are to be rethought about them. It is to be recognized that another proposal such as Gudynas' (2016) when he describes the transactions to post-extractivism, neglects the contributions of Ecofeminism in criticizing the development model. And, in his proposals, he does not visualize the necessary gender perspective to overcome the actual economic model.

Questions made by Escobar, such as what degree of veracity, what silencing effect brought about the development language?, help us understand what is hidden behind the growth. Does miningexploitation really mean the wellbeing this "development" is supposed to bring along with? This critique has been defined by Svampa (2017) as one of the keys to understand the epoch (starting with the 2000`s), through the concept of "Consensus of Commodities", with a new problematizing about "development". For Svampa:

the later critique to (neo) extractivism, which brings about a new questioning of the ideology of progress, illustrated nowadays by the expansion of extractive megaprojects (megamining, oil drilling, new agrarian capitalism with its combination of transgenic seads and agrotoxics, mega dams, great real state ventures, among others). These models represent the common extractive logic: great scale, orientation to exportation, intensive occupation of territory, land hoarding, increasing the environmental socio-sanitary impacts, preeminence of great transnational corporate actors and tendency to the low intensity democracy [...] (SVAMPA, 2017, p. 56).

The amplification of the exploitation borders and the uses of the territory in Southeastern Pará reinforce the violence of an economy based on patriarchal values as well as on the capitalist market that omits and destroys sources of life for the traditional population, such as women who make their living by breaking Babaçu coconut; "while neglecting the 
economic value of vital economies which are needed for human and ecological survival: the economy of nature and the economy of sustenance" (SHIVA; MIES, 2013, p. 19).

Visualizing the relationship between the exploitation and merchandizing of nature with the sexual exploitation of women and the merchandizing of our bodies has been fundamental for ecofeminism, Vandana Shiva has denounced the deterioration of the living conditions of poor rural women in the Third World due to "mal-development", as those women are the ones who best know the sinister face of "modernization" (SHIVA, 1995).

Again, we resort to Critical and Third World Ecofeminism to understand the impacts of socio-environmental conflicts for the life-sustaining productive practices; thus overcoming the dichotomy of modern rationality separating culture from nature, production from reproduction and its constituting hierarchies. "The affectionate distance and dual subject/object thinking take part in hegemonic androcentrism and they are tied to the exaggerated anthropocentrism of our vision of Nature" (PULEO, 2005, p. 206).

Thus ecofeminism is the key to deconstruct the androcentric and patriarchal biases of the system as a whole, ending up the separations and immobility of spheres and places assigned by modern thinking to men and women. It acknowledges the limits the system places to human and non-human life, considering as ethical principles like social responsibility for caring, including the care for nature. In the same extent that they reveal existing nexuses between patriarchy and capitalism, they show the devaluation suffered by the life-sustaining activities, historically performed by women, such as the reproductive work and the extractive-agricultural activities carried out as an extension of their domestic space.

The experience of the Babaçu coconut women breakers shows how poor women are the most affected by economic and environmental injustice. It also shows however how, at the same time, they are protagonists in the rise of resistance, defending their symbolic territory and the life of the palm trees, which is called by Martínez Alier (2005, 2015) "the poor people's ecology".

Asking ourselves how this reality is related to the life of women and why socioenvironmental conflicts are also feminist issues, lead us to analyze the extent of the materialization of conflicts and inequalities into their bodies. A reality in which several ways of hierarchic power are interrelated. Thus experiences of women are important to visualize the conflicts and their capacity for agency; which is understood here as "a capacity for created action, historically favored by concretely conformed subordinate relations" (MAHMOOD, 2006, p. 123).

Let us take as an example the struggle of women from traditional communities identified as Babaçu coconut breakers. Their symbolic territory is located in rural spaces at Tocantins river valley, especially at the municipalities of San Domingo do Uruguaia, Palestina, Brejo Grande and San Juan do Uruguaia.

Through generations, these women have supported their families from the income provided by extracting Babaçu coconut. These are women who live in conditions of great poverty with their bodies darkened in more than $90 \%$, under-schooled, pertaining to several generations marked by the patriarchal violence and by the expansion of transna- 
tional capitalism, incarnated in the agro-business and mineral exploitation, depraving them from the source of family maintenance: Babaçu coconut.

Their survival is threatened by the devastation of Babuçuais in favor of the development of the livestock farms, by means of either poisoning the palm-trees or by cutting them. Another most recent situation are the socio-environmental impacts of "predator extractivism" ${ }^{15}$ caused by the Vale Enterprising S.A., as the demand of charcoal to supply the industrial park of Marabá city, as well as the industries located in the state of Marañao stimulating the renting of the Babuçuais by the livestock farmers for the extraction of the full size coconut.

These conditions increase conflicts but also women action beyond the struggles for preserving the palm trees. It is a struggle for defending a symbolic territory with its landscape, its racial-ethnic identities and traditions as well as their rights as women to live and to be a part of this world. They organized in an interstate movement (MIQCB) (by its Spanish acronym). They have created cooperatives and they had passed the "Free Babaçu" Federal Act, and now they fight to get it enforced at the local scale.

One of these women leaders describes the struggle of the women coconut breakers, as it follows:

We mobilize ourselves and we go to the municipal chamber. We want
this law enforced, the landowners are poisoning the palm trees and
placing electric fences. They are selling the whole coconut to make
charcoal. They do not want to donate the coconut for the people.
When we make a report we are chased, women fighting with us are
threatened to death. Coconut trees are farer every time and the mu-
nicipality is less cooperative (FEMALE LEADER A, MIQCB, 2016).

Violence against women makes also the government responsible as it is not capable of enforcing the legislation already passed, when it is indifferent to the claims for support and for the threats and deaths of these women.

[...] we are so discriminated against that many times when we are finally able to get the coconut, it has already got dry and we cannot get the municipality support to transport it $[\ldots]$ we are not asking for food, we do ask for support to be able to produce [...]. Our struggle is for the Babaçu Free. It matters to all the women, we want women and palm trees alive (FEMALE LEADER B, MIQCB, 2016).

This speech not only expresses their actions but also the conditions of vulnerability these women and the palm trees are suffering. There is an interdependence between the coconut women breakers and the palm trees, an eco-dependency at risk due to the socio-environmental conflicts featuring the expansion of capital in Southeastern Pará.

15 - "Predator extrativism" is the term used by Gudynas 2016 to characterize the intensive and great scale extractivism and the externalization of social and environmental costs. 


\section{Final considerations}

Political Ecology, Ecofeminism as well as the studies about territory were epistemologically relevant to understand the complexity of socio-environmental conflicts in Southeastern Pará.

From a critical perspective, Ecofeminism shows socio-cultural webbings connecting the relations of our bodies to the ecosystems where we live; thus showing the keys to deconstruct essentialisms that identified women with nature.

Visualizing the connection between the exploitation and merchandizing of the land with the exploitation and merchandizing of the women's bodies has been fundamental in this approach. Theoretical approaches of post-development, as well as ecofeminist ones challenge the epistemic foundations of modernity over "development" and the ways to understand nature and the place of the women.

Dynamics around socio-environmental conflicts in Southeastern Pará may be classified as "high intensity" due to the multiplicity of actors in dispute, to the hybridization of their contents, the expressions of the resistances, languages, cultural sensitivity, the ways to perceive and value the territory, as well as the way in which they define and build divergent ontologies.

Understanding Southeastern Pará as a territory in dispute means understanding its historical logics, process through which the space reordering is made due to de-territorializing, losing the space and natural resources in favor of the big capitalist enterprising, including transnational capital.

The issues for land and its resources are the foundations on top of which all conflicts related to territory, water supplies, mining, hydroelectrics and all possible conflicts defined as socio-environmental ones are built and branched. These conflicts ravel different logics: of accumulation and life sustainability. And it is precisely this second logics the one that nourishes the experiences of the Babaçu coconut women breakers in Southeastern Pará. Their actions relate them to the care of the palm trees which, as a symbiosis, in the same way they understand it, is equal to fight for their own lives in a kind of ontological interdependence with the symbolic territory they take part of and defend.

\section{References}

ACSELRAD, H. Conflitos ambientais no Brasil. (org). Rio de Janeiro. Relumé Dumará: Fundação Henrich Boll, 2004.

. Disputas cognitivas e exercício da capacidade crítica: o caso dos conflitos ambientais no Brasil. Sociologias, Porto Alegre, ano 16, nº 35, jan/abr 2014, p. 84-105. Disponible en: https://www. scielo.br/scielo.php?pid $=$ S1517-45222014000100004\&script $=$ sci_abstract\&tlng $=$ pt. Acceso en: 04/6/2018.

ALMEIDA, A. W. B. de. Agroestratégias e Desterritorialização: direitos territoriais e étinicos na mira 
dos estrategistas dos Agronegócios. In: et. al. Capitalismo globalizado e recursos territoriais. Rio de Janeiro: Editora Lamparina, 2010.p. 101 - 141.

BOURDIEU, P. O poder simbólico. Rio de Janeiro: Bertrand Brasil, 1989.

COELHO, T. Projeto Grande Carajás: Trinta anos de desenvolvimento frustrado. In: ZONTA, M.; TROCATE, C. H. (org.). A questão mineral no Brasil, v. 1 p. 27-158. Editorial, Marabá, Pará, Brasil. 2015.

CPT-COMISSÃO PASTORAL DA TERRA. Conflitos no campo 2016. Centro de Documentação Dom Tomás Balduino. Goiânia-GO, 2017. Disponible en: www.cprnacional.org.br. Acceso en 23/10/2018.

. Conflitos no campo 2018. Centro de Documentação Dom Tomás Balduino. Goiânia-GO, 2019. Disponible en: www.cprnacional.org.br. Acceso en 28/12/2019.

ESCOBAR, A. El "postdesarrollo" como concepto y práctica social. In: MATO, D. (coord.). Políticas de economía, ambiente y sociedad en tiempos de globalización. Caracas: Facultad de Ciencias Económicas y Sociales, Universidad Central de Venezuela, 2005. p. 17-31.

. Una minga para el postdesarrollo: lugar, medio ambiente y movimientos sociales en las transformaciones globales. Lima: Universidad Nacional de San Marcos, 2010. Disponible en: https:// opsur.files.wordpress.com/2010/11/escobar-2010-unaminga.pdf. Acceso en: 15/07/2015.

ESTEVA, G. Más allá del desarrollo: la buena vida. In: Agonía de un mito ¿Cómo reformular el "desarrollo"? Rev. América Latina en movimento. Quito, 445, de junio: 1-5, 2009. Disponible en: https://www.alainet.org/sites/default/files/alai445w.pdf. Acceso en: 15/07/2015.

FERNANDES, B. M. MST - Movimento dos Trabalhadores Rurais Sem Terra: formação e territorialização em São Paulo. São Paulo: Ed. Hucitec. 1999. 285 p.

. Movimentos socioterritoriais e movimentos socioespaciais: contribuição teórica para uma leitura geográfica dos movimentos sociais. Revista Nera. Presidente Prudente, ano 8, n.6, p.14-32, jan-jun de 2005. Disponible en: https://revista.fct.unesp.br/index.php/nera/article/view/1460. Acesso en: 13/10/2019.

FONTAINE, G. Enfoques conceptuales y metodológicos para una sociología de los conflictos ambientales, Bogotá: Sociedad y Medio Ambiente, 2004. Disponible en: https:/library.fes.de/pdf-files/ bueros/kolumbien/01993/12.pdf. Acceso en: 30/10/2017.

FOUCAULT, M. O sujeito e o poder. [S.1.:,197? ]. Disponible en http://www.uesb.br/eventos/pensarcomfoucault/leituras/o-sujeto-e-o-poder.pdf Acceso en: 09/10/2017.

. História da sexualidade I: A vontade de saber. (14ª ed.). Rio de Janeiro: Edições Graal, 2001.

. A hermenêutica do sujeito. São Paulo: Martins Fontes, 2004.

FREITAS, E. O conceito de território e o agroartesanato. Revista Nera, Presidente Prudente, ano 
11, n. 13, jul-dez, p.83-101, 2008. Disponible em: http://www2.fct.unesp.br/nera/revistas/13/10_ eduardo_13.pdf. Acceso en: 28/4/2015.

GUDYNAS, E. Conflictos y extractivismos: conceptos, contenidos y dinámicas. DECURSOS, Revista en Ciencias Sociales, (CESU, Universidad Mayor San Simón, Cochabamba) 27-28, 79-115, 2014. Disponible en: https://horizontescomunitarios.files.wordpress.com/2016/09/gudynas-conflictosextractrivismosconceptosdecs14.pdf. Acceso en: 10/10/2017.

. El día después del desarrollo. Agonía de um mito ¿Cómo reformular el "desarrollo"? Revista América Latina en movimiento, Quito, 445, 31-33, 2009. Disponible en: Disponible en: https:// www.alainet.org/sites/default/files/alai445w.pdf. Acceso en: 15/07/2015

. "Extractivismos em America del Sur: conceptos y sus efectos derrame". In: ZHOURI, A; BOLADOS, P; CASTRO, E. Mineração na América do Sul: neoextrativismo e lutas territoriais. São Paulo: Anablume, 2016. p. 23-43

. Transições ao pós-extrativismo Sentidos, opções e âmbitos. IN: DILGER, G; LANG, M; PEREIRA J. Filho (orgs.). Descolonizar o imaginário. Debates sobre pós-extrativismo e alternativas ao desenvolvimento. São Paulo: Fundação Rosa Luxemburgo, 2016. p. 174-213.

HALL, A. L. Amazônia, Desenvolvimento para quem? Desmatamento e Conflito Social no Programa Grande Carajás. Rio de Janeiro: Jorge Zahar. 1991.

HARVEY, D. El “nuevo” imperialismo: acumulación por desposesión. Buenos Aires: CLACSO, 2004. Disponíble en: www.http://biblioteca.clacso.org.ar/clacso/se/20130702120830/harvey.pdf. Acceso en 15.3.2018.

HAESBAER, R. Des-territorialização e identidade: a rede "gaúcha" no Nordeste. Niterói: Ed UFF, 1997.

HÉBETTE. J. Cruzando fronteira. 30 anos de estudo do campesinato na Amazônia. V. III. Editora Universitária, UFPA, Belém, 2004.

IBASE- INSTITUTO BRASILERO DE ANÁLISIS SOCIALES Y ECONÓMICOS. Contradições do desenvolvimento e o uso da CFEM em Canaã dos Carajás. Disponible en: URL :http://ibase.br/pt/noticias/debate-sobre-uso-da- cfem-em-canaa-dos-carajas-pa-mobiliza-atores-locais/.12/09/2018. Acceso en 26.10.2018.

IBGE- INSTITUTO BRASILEIRO DE GEOGRAFÍA E ESTADÍSTICA. Cidades estimativa da população, em 2015.

LEFF, E. ¿De quién es la naturaleza? Sobre la reapropiación social de los recursos naturales. Gaceta Ecológica México. México: Nueva Época/ SEMARNAP, n. 37, 1995. XXI, 2004.

. Racionalidad Ambiental. La reapropiación social de la naturaliza. Buenos Aires: Siglo . La ecología política en América Latina. Un campo en construcción, en: Los tormentos 
de la materia. Aportes para una Ecología Política latinoamericana (ALIMONDA Héctor). Buenos Aires: CLACSO, 2006. p. 21-40.

MACHADO ARÁOZ, H. "Ecología política de los regímenes extractivistas. De reconfiguraciones imperiales y re-ex-sistencias decoloniales” en Nuestra América. Revista Bajo el Volcán, ${ }^{\circ}$ 23. Puebla: Benemérita Universidad Autónoma de Puebla, 2015

MAHMOOD, S. Teoría feminista, Agência e sujeto liberatório: algumas reflexôes sobre o revivalismo islâmico no Egipto. Etnográfica, Portugal, v. X (1), p. 121-158, 2006.

MARTINS, J. de S. A Chegada do Estranho. São Paulo. Editora Hucitec, 1993.

. Fronteira a degradação do outro nos confins do humano. São Paulo. Contexto, 2016.

MARTÍNEZ ALIER, J. La economía ecológica como ecología humana. Fundación César Manrique: Lanzarote (Islas Canarias). 1998.

. "Los Conflictos Ecológico-Distributivos y los Indicadores de Sustentabilidad". Revista Iberoamericana de Economía Ecológica, Rio de Janeiro, v. 1. 2004.

. El Ecologismo de los Pobres. Conflictos Ambientales y Lenguajes de Valoración. Icaria: Barcelona, 2005.

- Algunas relaciones entre la Economía Ecológica y la Ecología Política en América Latina. En Razón y Fe, España, t. 272, nº, 1404, p. 239-250, 2015.

MARX, K. El Capital. Capítulo XXV Tomo 1. La Acumulación Originaria del Capital. Editorial Progreso, Moscú, 1975.

MIES, M; SHIVA, V. La praxis del ecofeminismo: biotecnologia, consumo, reproducción. Barcelona: Icaria Editorial, 1998.

PEREIRA, A. dos R., A luta pela terra no sul e Sudeste do Pará: migrações, conflitos e violência no campo. Tese (Doutorado em História) - UFPE, Recife (PE), 2013.

PINASSI M. O; CRUZ NETO, R. G. da, A mineração e a lógica da produção destrutiva na Amazônia. In: TROCATE, C. (ed.). Iguana: Reflexão Amazônica. Marabá: Editorial Iguana. 2015. p. 80-99.

PULEO, A. Los dualismos opresivos y la educación ambiental. ISEGORÍA, Madrid, nº. 32, p. 201-214, 2005. $\overline{2011 / 2012 .}$

. Ecofeminismo para otro mundo posible. Ecologista, Madrid, no .71, p. 54-55, invierno

RAFFESTIN, C. Por uma geografia do poder. São Paulo: Ática, 1993.

RIBEIRO JUNIOR, R. Akrâtikatêjê: dominação e resistência na luta por seu território. Dis- 
sertação (Mestrado em Dinâmicas Territoriais e Sociedade na Amazônia). Mestrado-PDTSA, Unifesspa, Marabá, 2014.

SAQUET, M. Os tempos e os territórios da colonização italiana. Porto Alegre: EST Edições. 2003.

SHIVA, V. Abrazar la vida. Mujer, ecología y desarrollo. Horas y Horas, Madrid, 1995.

. Las nuevas guerras de la globalización; semillas, agua y formas de vida. España: Editorial Popular, 2007.

.; MIES, M. Ecofeminismo. Teoría, Crítica y Perspectivas. Icaria. Barcelona. 2013. Disponible en: http://www.icariaeditorial.com/pdf_libros/ecofeminismo.pdf. Acceso en 21/11/2017.

SVAMPA, M. Cuatro claves para leer América Latina. 2017. Disponible en: www.nuso.org. Acceso en 20/12/2019.

. Cambio de época. Movimientos sociales y poder político. Buenos Aires: Siglo XXI, 2008.

. VIALE, E. Maldesarrollo. La Argentina del extractivismo y el despojo. Buenos Aires: Katz, 2014. Disponible en: https://repositorio.uca.edu.ar/handle/123456789/5646. Acceso en: 28/12/2019.

THOMAS, K. O homem e o mundo natural. Mudanças de atitude em relação as plantas e aos animais. (1500-1800). São Paulo: Companhia das Letras, 2010.

WANDERLEY, N. B. A sociologia do mundo rural e as questões da sociedade no contemporânea. Ruris, São Paulo, v.4, n.1, p. 21-36, 2011. Disponible en: https:/www.google.com/search?client=firefox$-\mathrm{b}-\mathrm{d} \& \mathrm{q}=\mathrm{A}+$ sociologia $+\mathrm{do}+$ mundo + rural $+\mathrm{e}+\mathrm{as}+\mathrm{quest} \% \mathrm{C} 3 \% \mathrm{~B} 5 \mathrm{es}+\mathrm{da}+$ sociedade + no $+\mathrm{co}$ ntempor\%C3\%A2nea. Acceso en 14/03/2018.

WARREN, K. Filosofías ecofeministas. Barcelona (España): Icara, 2003. Disponible en: http:// ez.urosario.edu.co/login?url=http://se.... Acceso en 06/01/2020. 
María de los Ángeles Guevara

ఐ ariasguevara2011@gmail.com

https://orcid.org/0000-0001-6260-8861
Submitted on: 22/10/2018

Accepted on: 24/07/2020

2020;23:e02521

\section{Edma Silva Moreira}

ఐedma@unifesspa.edu.br

https://orcid.org/0000-0001-9198-8680

How to cite: GUEVARA, M. A.; MOREIRA, E. S. Socio-environmental conflicts and the struggles for the Southeast territory of Pará. Ambiente \& Sociedade. São Paulo, v. 23, p. 1-22, 2020. 


\title{
Conflitos socioambientais, a luta pela terra e o território no Sudeste paraense
}

\author{
Maria de los Ángeles Guevara \\ Edma Silva Moreira
}

São Paulo. Vol. 23, 2020

Artigo Original
Resumo: Na Amazônia Oriental, os conflitos socioambientais aumentam à medida que sua riqueza é valorizada pelo capital transnacional, base para a reconcentração da terra de acordo com os interesses globais. O objetivo do estudo é refletir sobre as dinâmicas sócio territoriais que envolvem conflitos socioambientais e lutas de uma multiplicidade de atores sociais pelos seus direitos. A metodologia seguida é derivada da experiência de trabalho de campo das autoras observadoras diretas do contexto do estudo, da condução das entrevistas e da leitura e interpretação das fontes. Os resultados mostram que a questão agrária constitui a base sobre a qual outros conflitos são construídos e ramificados, podendo ser definidos como conflitos socioambientais. As resistências aos processos da desterritorialização das populações camponesas e tradicionais resinificam o papel dos atores sociais na luta pelo território.

Palavras-chave: Amazônia Oriental; Conflitos socioambientais; Poder; Lutas sociais.

Como citar: GUEVARA, M. A.; MOREIRA, E. S. Conflitos socioambientais, a luta pela terra e o território no Sudeste paraense. Ambiente \& Sociedade. São Paulo, v. 23, p. 1-22, 2020.

DOI: http://dx.doi.org/10.1590/1809-4422asoc20180252r1vu2020L6AO 


\title{
Conflictos socioambientales, la lucha por la tierra y el territorio en el sudeste del Pará
}

\author{
María de los Ángeles Guevara \\ Edma Silva Moreira
}

São Paulo. Vol. 23, 2020

Artículo original
Resumen: En la Amazonia Oriental los conflictos socioambientales se acrecentan en la medida en que sus riquezas son valorizadas por capital trasnacional, base para la reconcentración de la tierra en función de intereses globales. El objetivo del artículo es reflexionar sobre las dinámicas socioterritoriales que envuelven conflictos socioambientales y las luchas de una multiplicidad de actores sociales por sus derechos. La metodología seguida se deriva de la experiencia del trabajo de campo de las autoras observadoras directas del contexto de estudio, la realización de entrevistas y la lectura e interpretación de fuentes. Los resultados muestran que, la cuestión agraria constituye la base sobre la que se construyen y ramifican otros conflictos, todos ellos posibles a definir como conflictos socioambientales. Las resistencias a los procesos de desterritorialización de las poblaciones campesinas y tradicionales resignifican el papel de los actores sociales en la lucha por el territorio.

Palabras-clave: Amazonía Oriental; Conflictos Socioambientales; Poder; Luchas Sociales.

Como citar: GUEVARA, M. A.; MOREIRA, E. S. Conflictos socioambientales, la lucha por la tierra y el territorio en el sudeste del Pará. Ambiente \& Sociedade. São Paulo, v. 23, p. 1-23, 2020.

DOI: http://dx.doi.org/10.1590/1809-4422asoc20180252r1vu2020L6AO 